\title{
Mange skin diseases in dogs and cats in Jataí, Brazil: A retrospective study with notes on zoonotic aspects
}

Dermatopatias por sarnas em cães e gatos em Jataí, Brasill: Estudo retrospectivo com notas em aspectos zoonóticos

Cicatrices cutáneas en perros y gatos en Jataí, Brasil: estudio retrospectivo con notas sobre aspectos zoonóticos

Thâmara Rossi Martins da Silva ORCID: https://orcid.org/0000-0002-5788-0665 Universidade Federal de Jataí, Brasil E-mail: thamara.rossi@hotmail.com

Micael Siegert Schimmunech

ORCID: https://orcid.org/0000-0001-8610-8052 Universidade Federal de Jataí, Brasil E-mail: micaelsiegert@hotmail.com

Priscilla Juliane Kirchhoff Pott ORCID: https://orcid.org/0000-0002-1082-8835 Universidade Federal de Jataí, Brasil E-mail: priscillakirchhoff@gmail.com Ana Vitória Alves-Sobrinho ORCID: https://orcid.org/0000-0001-8521-2210 Universidade Federal de Jataí, Brasil E-mail: anavitsobrinho@outlook.com

Priscila Gomes de Oliveira ORCID: https://orcid.org/0000-0002-6151-799X Universidade Federal de Goiás, Brasil E-mail: vet.priscilagomes@gmail.com

Andréia Vitor Couto do Amaral ORCID: https://orcid.org/0000-0001-6406-2372 Universidade Federal de Jataí, Brasil E-mail: andreiavcvet@ufg.br

Klaus Casaro Saturnino ORCID: https://orcid.org/0000-0001-8493-8669 Universidade Federal de Jataí, Brasil E-mail: klaus.sat@ufg.br Alana Flávia Romani

ORCID: https://orcid.org/0000-0002-8138-408X Universidade Federal de Jataí, Brasil E-mail: alana_romani@ufg.br

Dirceu Guilherme de Souza Ramos ORCID: https://orcid.org/0000-0001-9603-6638 Universidade Federal de Jataí, Brasil E-mail: dgramos_vet@hotmail.com

\begin{abstract}
The parasitic skin diseases, specifically mange diseases, are highly relevant in the animal health studies, due to a significant number of cases in the veterinary routine, beyond the importance in public health, due to zoonotic potential. Therefore, this study aimed report the occurrence of mange skin diseases with notes in the zoonotic potential from Jataí, Goiás, by an retrospective survey of mange cases diagnosed in dogs and cats treated at the Veterinary Hospital of the Federal University of Jataí. A total of 612 reports of parasitological tests, comprising cerumen swabs and skin scraping, were analyzed from January 2016 to December 2019. The most common causative mite in dogs was Demodex canis (10.94\%), followed by Otodectes cynotis (2.92\%), and Sarcoptes scabiei (2.54\%). The most common causative mite in cats was Notoedres cati (20\%), followed by O. cynotis (10\%). These skin diseases are characterized as being highly contagious; therefore, these can be easily transmitted among animals and even humans. In addition, intense itching and skin lesions lead to discomfort, consequently causing stress to the
\end{abstract}


animals. Thus, mite control as well as prompt diagnosis and treatment are relevant to manage these skin diseases and ensure animal welfare.

Keywords: Alopecia; Dermatology; Mites; Parasitology.

\begin{abstract}
Resumo
As dermatopatias parasitárias, em especial as sarnas, possuem grande relevância no estudo de saúde animal, devido à expressiva casuística na rotina veterinária, além da importância em saúde pública, devido ao potencial zoonótico. Portanto, este estudo teve como objetivo relatar a ocorrência de dermatopatias com apontamentos no potencial zoonótico de Jataí, Goiás, por meio de um levantamento retrospectivo de casos de sarna diagnosticados em cães e gatos atendidos no Hospital Veterinário da Universidade Federal de Jataí. Foram analisados 613 laudos de exames parasitológicos, constituídos de parasitológicos de cerúmen e de raspados de pele, no período de janeiro de 2016 a dezembro de 2019. O ácaro de maior ocorrência nos cães foi o Demodex canis (10,94\%), seguido pelo Otodectes cynotis $(2,92 \%)$ e Sarcoptes scabiei (2,54\%). Em gatos, o Notoedres cati (20\%) foi o mais diagnosticado, seguido pelo O. cynotis (10\%). Essas sarnas caracterizam-se por ser altamente contagiosas, portanto, são facilmente transmissíveis entre os animais, e algumas delas aos seres humanos. Além disso, o intenso prurido e o aparecimento de lesões cutâneas causam incômodo e, consequente, estresse ao animal. Desse modo, o diagnóstico e o tratamento, assim como a prevenção aos ácaros, são relevantes no controle dessas dermatopatias e preservação do bem-estar animal.
\end{abstract}

Palavras-chave: Alopecia; Dermatologia; Ácaros; Parasitologia.

\title{
Resumen
}

Las dermatopatías parasitarias, especialmente la sarna, tienen gran relevancia en el estudio de la salud animal, por la expresiva casuística en la rutina veterinaria, además de la importancia en salud pública, por el potencial zoonótico. Por tanto, este estudio tuvo como objetivo reportar la ocurrencia de enfermedades de la piel con apuntes sobre el potencial zoonótico de Jataí, Goiás, a través de una encuesta retrospectiva de casos de sarna diagnosticados en perros y gatos atendidos en el Hospital Veterinario de la Universidad Federal de Jataí. Se analizaron 613 reportes de exámenes parasitológicos, consistentes en parásitos del cerumen y raspaduras de piel, entre enero de 2016 y diciembre de 2019. El ácaro más frecuente en perros fue Demodex canis (10,94\%), seguido de Otodectes cynotis (2,92\%) y Sarcoptes scabiei (2,54\%). En gatos, Notoedres cati (20\%) fue el más diagnosticadas, seguido de O. cynotis (10\%). Estas costras se caracterizan por ser altamente contagiosas, por lo que se transmiten fácilmente entre animales, y algunas de ellas a los humanos. Además, el picor intenso y la aparición de lesiones cutáneas provocan malestar y, en consecuencia, estrés al animal. Así, el diagnóstico y tratamiento, así como la prevención de los ácaros, son relevantes en el control de estas enfermedades de la piel y la preservación del bienestar animal.

Palabras clave: Alopecia; Dermatología; Ácaros; Parasitología.

\section{Introduction}

Dermatological diseases account for approximately $30 \%$ cases in the clinical routine in a veterinary hospital, representing a growing problem in veterinary medicine, since these can trigger severe skin pathologies, causing discomfort and consequent stress to the animals, in addition to traumatic wounds that can lead to secondary infections (Scott et al., 2013).

Dermatitis caused by mange mites is among the common parasitic skin diseases. Demodex canis, Sarcoptes scabiei, Otodectes cynotis, and Notoedres cati are the notable causative mite species commonly diagnosed as causative agents in small animal clinics (Batista et al., 2013). In addition to their transmission among animals, some mites, such as $S$. scabiei and $O$. cynotis, have zoonotic potential (Moriello, 2003); however, N. cati parasitism has also been reported in humans (Brum et al., 2007).

S. scabiei and $N$. cati affect dogs and cats, respectively. They are transmitted through either direct contact with infected animals or people or indirect contact with contaminated fomites (Scott et al., 2013). The lesions are characterized by hemorrhagic crusts and intense itchiness, along skin thickening, and mainly occur on the head, neck, and ears (Urquhart et al., 1998; Brum et al., 2007). D. canis affects dogs and is not considered a zoonotic mange (Moriello, 2003). They are found in hair follicles and sebaceous glands, causing folliculitis and alopecia (Wilkinson and Harvey, 1997), in addition to skin lesions that can become generalized, thereby increasing the severity of the condition due to the development of hemorrhage and 
secondary bacterial infections (Santarém, 2007). O. cynotis causes otitis externa in dogs and cats. Symptoms vary from erythema to otohematomas and exudation, causing pain, intense ear itching, and a characteristic odor (Gotthelf, 2004; Rosser, 2004; Rosychuk and Luttgen, 2004).

Definitive diagnosis of infestation with these parasites is based on mite visualization in the material to be analyzed. Skin scraping is the most common and accurate identification method for mites such as $N$. cati and S. scabiei (Ettinger and Feldman, 2004). In cases of suspected $O$. cynotis infestation, the auditory canal is searched for mites using an otoscope. However, if mites are not visualized, material from the auditory canal is collected to perform cerumen examination (Perego et al., 2014; Milley et al., 2017). D. canis infestation is also diagnosed based on parasite visualization, and material for analysis is collected by deep scraping of the lesioned areas, pressing the skin such that the mite is expelled from the hair follicle.

This article summarizes the results of a retrospective study of mange skin diseases diagnosed in dogs and cats treated at the Veterinary Hospital of the Federal University of Jataí and discusses relevant zoonotic aspects.

\section{Materials and Methods}

This study is a quantitative case study as described by Pereira et al. (2018). The qualitative aspect or phenomenon analyzed was the presence or absence of parasites caused by mange mites in animals treated by the Dermatology sector at the Veterinary Hospital of the Federal University of Jataí. With the database established, the occurrence was quantified in percentage values by mite species and separated into two groups of hosts (dogs and cats).

The study involved a retrospective analysis of parasitological data obtained though skin scraping and cerumen examinations performed in dogs and cats at the Veterinary Hospital of the Federal University of Jataí, Goiás, from January 2016 to December 2019. The examinations were performed according to the relevant animal welfare rules, since the operation of the hospital is subject to the rules of the Ethics Committee on the Use of Animals (CEUA) of the Federal University of Jataí.

For analysis, local hospital data of animals that presented with cutaneous lesions and underwent the two specific examinations for the diagnosis of the primary cause mentioned above were used.

Skin scraping was performed with a surgical scalpel by repeated scraping movements. When the diagnostic suspicion included mange caused by D. canis, the scraping was deep, until there was capillary bleeding. For cerumen examination, material in the external auditory canal of the animal was swabbed. Cerumen swabs were used for the diagnosis of $O$. cynotis infestation, as it is the recommended diagnostic test for this species. Subsequently, the samples were placed on glass slides and immersed in mineral oil for observation under an optical microscope at 10x and 40x magnifications.

The results were tabulated in spreadsheets. Descriptive data analysis was performed with the examination type, animal species, and identified mite species as variables.

\section{Results}

A total of 612 reported were analyzed, of which $512(83.66 \%)$ were for dogs and $100(16.34 \%)$ were for cats. Of the 512 dog samples, 406 were skin scrapings $(406 / 512,79.3 \%)$ and 106 were cerumen swabs (106/512, 20.7\%). Overall, 84 dogs were diagnosed with mange mite diseases $(84 / 512,16.4 \%)$. The most prevalent causative mite in dogs was $D$. canis, detected in 56 positive samples $(56 / 512,10.94 \%)$. Moreover, O. cynotis was detected in 15 positive samples $(15 / 512,2.92 \%)$, and $S$. scabiei in 13 positive samples $(13 / 512,2.54 \%)$. Of the 100 cat samples, 74 were skins scrapings $(74 / 100,74 \%)$ and 26 were cerumen swabs (26/100, 26\%). Overall, 30 cats were diagnosed with mange mite diseases (30/100, 30\%). Only two species of 
mites were identified: $N$. cati in 20 positive samples $(20 / 100,20 \%)$ and O. cynotis in 10 positive samples $(10 / 100,10 \%)$. All occurrences are listed in Table 1.

Table 1. Mange mite occurrences in dogs and cats treated at the Veterinary Hospital of the Federal University of Jataí, Goiás, from 2016 to 2019.

\begin{tabular}{|c|c|c|c|c|}
\hline \multirow{2}{*}{ Mite species } & \multicolumn{2}{|c|}{ Dogs } & \multicolumn{2}{|c|}{ Cats } \\
\hline & Positive & $\%^{\mathrm{c}}$ & Positive & $\%^{\mathrm{d}}$ \\
\hline Demodex canis ${ }^{\text {a }}$ & 56 & 10.94 & - & - \\
\hline Sarcoptes scabie $i^{\text {a }}$ & 13 & 2.54 & - & - \\
\hline Notoedres cati ${ }^{\text {a }}$ & - & - & 20 & 20 \\
\hline Otodectes cynotis ${ }^{\mathrm{b}}$ & 15 & 2.92 & 10 & 10 \\
\hline Total & 84 & 16.4 & 30 & 30 \\
\hline
\end{tabular}

${ }^{a}$ Skin scraping diagnosis; ${ }^{b}$ Cerumen swab diagnosis; ${ }^{c}$ Relative to 512 dog samples; ${ }^{\mathrm{d}}$ Relative to 100 cat samples. Source: Veterinary Hospital of Federal University of Jataí.

\section{Discussion}

According to Ettinger and Feldman (2004), skin lesions can be caused by several agents, such as fungi, bacteria, protozoa, ticks, and mites; therefore, diagnosis of the primary cause is crucial to select an effective treatment. Of the 612 test reported analyzed in this study, 114 were positive for mange mites, indicating that the tegumentary lesions present in the examined animals were caused by mite infestation. Moreover, misdiagnosis would lead to inadequate treatment, ultimately aggravating the clinical condition.

D. canis was the most prevalent causative species in dogs. The higher proportion of positive cases might be due to the predisposing factors that lead to a greater frequency of development of this disease in the clinical setting. Mundell (2003) highlighted some factors that may favor the development of demodicosis, such as malnutrition, parturition, and lactation. Moreover, according to Foster et al. (2005), immunosuppressive diseases, diabetes mellitus, neoplasms, and hyperadrenocorticism facilitate parasitism. However, it is essential to perform the examination accurately by deep scarping, such that the mites are exposed from the follicle, to avoid false negatives and obtain reliable results. Although demodicosis is not transmitted to humans from animals, its high prevalence should be highlighted owing to the clinical presentation and possibility of worsening of this condition. Secondary bacterial infections can progress to the development of follicular pustules, crusts, exudation, and ulcerations, and severely affected dogs can develop septicemia and even die (Mueller et al., 2020). According to Bensingnor and Carlotti (2000), 10\% cases of localized demodicosis progress to generalized demodicosis; thus, early diagnosis and treatment are important to prevent disease spread.

The prevalence of S. scabiei (2.54\%) was not high in this study. In a previous study at the Faculty of Veterinary Medicine and Zootechnics, University of São Paulo, 6.4\% of the skin disease cases treated from 1984 to 2002 were caused by sarcoptic mange (Larsson, 2016). According to Alasaad et al. (2013), since S. scabiei is a zoonotic mange, 30 to $50 \%$ of the canine mange cases can be transmitted to humans, indicating that correct diagnosis is crucial regardless of its low prevalence. In another study at the Federal University of Goiás, $17.8 \%$ of the skin disease cases treated from 2012 to 2013 were zoonotic, with $10 \%$ of these diagnosed as sarcoptic mange (Batista et al., 2013). Although this mite was not found in cats in the present study, this parasite is highly relevant to the feline clinics as well. Thus, in addition to being characterized as one of the most common mites in the clinical setting, S. scabiei is of great importance in the context public health as it causes a highly contagious disease in humans. 
$N$. cati accounted for $20 \%$ of the mange cases detected in the cat samples analyzed in this study and was, therefore, the most prevalent species in felines. According to Sloss et al. (1999), N. cati mange is a highly contagious and an easily transmitted disease among cats. Lefkaditis (2015) reported a higher prevalence of this disease in stray cats due to predisposing factors such as long hair, malnutrition, and co-infections. Being zoonotic, the prevalence of $N$. cati infestation in humans is increasing due to their growing contact with cats. According to Batista et al. (2013), 30\% of skin disorders identified as zoonoses are notohedral mange.

O. cynotis was more frequent in cats than in dogs, possibly because it is a highly contagious mange, which facilitates transmission. In a study by Beugnet et al. (2014) in seven European countries, O. cynotis was the most prevalent ectoparasite of domestic cats. In this study, $5.26 \%$ of the total cats presented co-infestation of otodectic and notohedral mange, which may facilitate the detection of $O$. cynotis in skin scrapings. Considering its zoonotic nature and presence in both dogs and cats, the transmission of $O$. cynotis to humans occurs mainly due to the lack of care after the treatment of the animals' auditory canal (Moriello, 2003). In a study by Ferreira et al. (2010), co-infestation of $O$. cynotis and $N$. cati was observed in both domiciled and stray cats. Similarly, in a study by Chaves et al. (2004), co-infestation of O. cynotis and N. cati was observed in domiciled cats in São Luís, Maranhão. Of note, considering the total number of tests that were performed exclusively for $O$. cynotis detection (cerumen examination), the number of suspected cases of $O$. cynotis infestation was much lower than that of the other mange mite species in animals (480 skin scrapings versus 132 cerumen examinations). This may be because the number species that affect the animal's body is greater than the number of species that affect the auditory canal.

Furthermore, considering that $5 \%$ of the skin diseases in humans are linked to animal ectoparasites (Brum et al., 2007) and $50.43 \%$ of the positive animals in the present study were infested with zoonotic mites, it is important that the animal owners are well-informed about these diseases and their possible transmission to humans.

Although most mites are host-specific, they can cause mange in humans. Although these mites cannot complete their life cycles in human hosts, they can trigger inflammatory reactions in the skin. Sarcoptic, notohedral, and otodectic mange cause lesions in humans, which are manifested by papulovesicular eruptions, eczema, crusts, itching, and abrasions (Brum et al., 2007). Moreover, O. cynotis can inhabit the external ear canal, causing irritation and transitional papular dermatitis (Lopez, 1993; Lefkaditis et al., 2015).

Since infestation is self-limiting, the associated lesions can regress if there is no contact with the infested animal (Paterson, 2009; Taylor et al., 2017). Therefore, it is necessary to take optimum care, specifically in terms of the animal's treatment, such as using gloves and disposable clothes to protect the guardian.

\section{Conclusion}

The large number of reports analyzed in the study reflects the importance of complementary examinations in confirming diagnostic suspicions in dermatology and, consequently, in selecting the therapeutic conduct. Mange is frequently diagnosed in veterinary clinical practice, and the occurrence of mites with zoonotic potential is relevant to public health. Considering that dogs and cats share the family environment at different degrees, these mites can be easily transmitted, favoring parasitism in humans. Thus, veterinarians must be aware of dermatozoonosis to implement appropriate treatment and prophylactic measures.

Studies on the occurrence of scabies mites in small animals are essential, especially considering that the occurrence fluctuates over the years, and these data are essential for strategies of education and prevention of cases in humans. New studies, which may include microregions or even provinces, are essential in the future, considering the particularities of each 
region, in addition to encouraging studies that analyze the use of medicines and their effectiveness in animals in each area, or even test new drugs or chemicals that can be found in the biome where the study was performed.

\section{References}

Alasaad, S., Rossi, L., Heukelbach, J., Pérez, J. M., Hamarsheh, O., Otiende, M., \& Zhu, X. Q. (2013). The neglected navigating web of the incomprehensibly emerging and re-emerging Sarcoptes mite. Infection, genetics and evolution: journal of molecular epidemiology and evolutionary genetics in infectious diseases, 17, 253-259. https://doi.org/10.1016/j.meegid.2013.04.018.

Batista, J. F., Vulcani, V. A. S., Camilo, E. D. F., Oliveira, A. F., \& Romani, A. F. (2013). Estudo retrospectivo da casuística de dermatopatias de caráter zoonótico do Hospital Veterinário do campus Jataí/UFG-GO. Ars Veterinaria, 29(4), 115-122. http://dx.doi.org/10.15361/2175-0106.2013v29n4p115

Bensignor, E., \& Carlotti, D. N. (2000). O que fazer frente a um cão com sarna demodécica. A Hora Veterinária, 20 (17), 29-33.

Beugnet, F., Bourdeau, P., Monfray, K. C., Cozma, V., Farkas, R., Guillot, J., Halos, L., Joachim, A., Losson, B., Miró, G., Otranto, D., Renaud, M., \& Rinaldi, L. (2014). Parasites of domestic owned cats in Europe: co-infestations and risk factors. Parasites and Vectors, 7, 291. https://doi.org/10.1186/1756$3305-7-291$

Brum, L. C., Conceição, L. G., Ribeiro, V. M., \& Haddad, V. (2007). Principais dermatoses zoonóticas de cães e gatos. Clínica Veterinária, 69(12), 29-46.

Chaves, E., Feitosa, M., Reis, L., Guerra, R., Santos, A., \& Ribeiro, A. (2004). Prevalência de ectoparasitos em gatos domésticos (Felis catus) na cidade de São Luís-MA. Revista Brasileira de Parasitologia Veterinária, 13(1), 348.

Ettinger, S. F., \& Feldman, E. C. (Ed). (2004). Tratado de Medicina Interna Veterinária Doenças do cão e do gato (5.ed.). Guanabara Koogan.

Ferreira, D. R. A, Alves, L. C., \& Faustino, M. P. G. (2010). Ectoparasitos de Felis catus domesticus (Linnaeus, 1758) na cidade de João Pessoa, Paraíba, Brasil. Biotemas, 23(4), 43-50. https://doi.org/10.5007/2175-7925.2010v23n4p43

Foster, A. P., Hillier, A., \& Kwochka, K. W. (Ed). (2005). Advances in Veterinary Dermatology (5a ed.). Blackwell Pub.

Gotthelf, L. N. (Ed). (2004). Small animal ear diseases: an illustrated guide (2a ed.). Saunders.

Larsson, C. E. (Ed). (2016). Tratado de Medicina Externa Dermatologia veterinária (2a ed.). Interbook.

Lefkaditis, M. A., Sossidou, A. V., Panorias, A. H., Koukeri, S. E., Paştiu, A. I., \& Athanasiou, L. V. (2015). Urban stray cats infested by ectoparasites with zoonotic potential in Greece. Parasitology Research, 114(10), 3931-3934. https://doi.org/10.1007/s00436-015-4688-4

Lopez, R. A. (1993). Of Mites and Man. Journal of the American Veterinary Medical Association, 203(5), 606-607.

Milley, C., Dryden, M., Rosenkrantz, W., Griffin, J., \& Reeder, C. (2017). Comparison of parasitic mite retrieval methods in a population of community cats. Journal of Feline Medicine and Surgery, 19(6), 657-664. https://doi.org/10.1177/1098612X16650717

Moriello, K. A. (2003). Zoonotic skin diseases of dogs and cats. Animal Health Research Reviews, 4(2), 157-168. https://doi.org/10.1079/ahr200355

Mueller, R. S., Rosenkrantz, W., Bensignor, E., Karaś-Tęcza, J., Paterson, T., \& Shipstone, M. A. (2020). Diagnosis and treatment of demodicosis in dogs and cats - Clinical consensus guidelines of the World Association for Veterinary Dermatology. Veterinary Dermatology, 31(1), 5-27. https://doi.org/10.1111/vde.12806

Mundell, A. C. Demodicose. In: Birchard, S. J., \& Sherding, R. G. (Ed). (2003). Clínica de Pequenos Animais. Roca, $329-334$.

Paterson, S. (Ed). (2009). Manual of Skin Diseases of the Dog and Cat (2a ed.). Blackwell Publishing.

Perego, R., Proverbio, D., Bagnagatti De Giorgi, G., Della Pepa, A., \& Spada, E. (2014). Prevalence of otitis externa in stray cats in northern Italy. Journal of Feline Medicine and Surgery, 16(6), 483-490. https://doi.org/10.1177/1098612X13512119

Pereira, A. S., Shitsuka, D.M., Parreira, F. J. \& Shitsuka, R. (2018). Metodologia da Pesquisa Científica. UFSM NTE.

Rosser, E. F. (2004). Causes of otitis external. The Veterinary clinics of North America. Small animal practice, 34(2), 459-68. https://doi.org/10.1016/j.cvsm.2003.10.006

Rosychuk, R. A. W., \& Luttgen, P. (Ed). (2004). Textbook of veterinary internal medicine (8a ed.). Saunders.

Santarem, V. (2007). Demodiciose canina: Revisão. Clínica Veterinária, 69, 86-95.

Scott, D., Miller, W., \& Griffin, C. (Ed). (2013). Muller and kirk's Small Animal Dermatology (7a ed.). Saunders.

Sloss, M.W., Zajac, A. M., \& Kemp, R. L. (Ed). (1999). Parasitologia clínica veterinária (6a ed.). Manole.

Taylor, M. A., Coop, R. L., \& Wall, R. L. (Ed). (2017). Parasitologia Veterinária (4a ed.). Guanabara Koogan.

Urquhart, G. M., Armour, J., Duncan, J. L. Dunn, A. M., Jennings, F. W. (Ed). (1998). Parasitologia Veterinária (2a ed.). Guanabara Koogan. 
Research, Society and Development, v. 10, n. 1, e10610111417, 2021 (CC BY 4.0) | ISSN 2525-3409 | DOI: http://dx.doi.org/10.33448/rsd-v10i1.11417

Wilkinson, G. T., \& Harvey, R. G. (Ed). (1997). Atlas Colorido de Dermatologia dos Pequenos Animais (2a ed.). Manole. 